\title{
El reverso de la censura. Cine clandestino durante el tardofranquismo y la Transición
}

\author{
MATEO LEIVAS, Lidia \\ CENDEAC, Murcia, 2020 \\ ISBN: 978-84-15556-69-5
}

\author{
O todos o ninguno. O todo o nada. \\ Uno solo no puede salvarse. \\ O los fusiles o las cadenas. \\ O todos o ninguno. O todo o nada.
}

Brecht, 1999: 46

Manuel González, trabajador de la fábrica Laforsa, toma la palabra mientras mira a cámara: presenta la huelga en nombre de sus compañeros, «la más larga en Cataluña desde 1939». Lo rodean, a ambos lados, Mariano Lisa y Helena Lumbreras, fundadores del Colectivo Cine de Clase y responsables de la película. "Os ofrecemos nuestra experiencia, para que así nuestra lucha se entienda y alcancemos los objetivos como pueblo y como clase», culmina González, dando paso a escenas de asambleas, manifestaciones, cargas policiales. El filme se ofrece como documento o testimonio histórico, pero también como herramienta para la lucha en Laforsa. Se trata de O todos o ninguno (1976), una de las películas abordadas por Lidia Mateo Leivas en su publicación, quien señala la originalidad de que, en esta ocasión, los cineastas expongan sus nombres y rostros (2020: 7374). La clandestinidad imponía discreción, pero, en el caso de Laforsa, que había logrado activar una respuesta solidaria en multitud de fábricas aledañas -la célebre «mancha de aceite»- durante un año, el consenso social brindaba una seguridad inapelable. Descubrimos así, siguiendo a Mateo, cómo la «zona de sombra» dibujada por la censura tardo y postfranquista fluctuaba, negociando sus contornos en virtud de los acontecimientos.

Como indica su título, el libro se articula en torno a la reflexión sobre la censura y sus contrapartes en el medio cinematográfico, proyectadas como un juego de espejos.

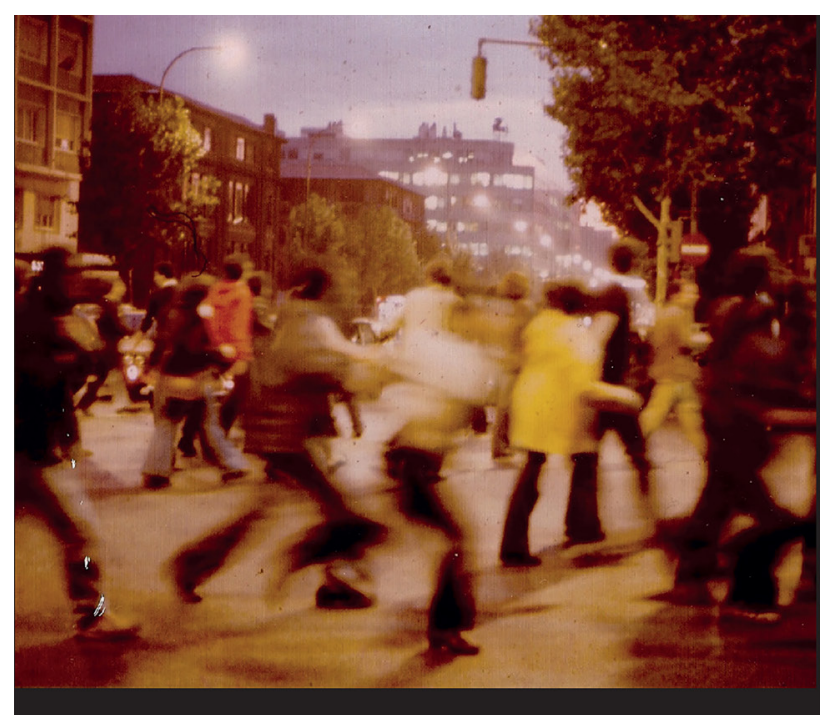

LIDIA MATEO LEIVAS

EL REVERSO DE LA CENSURA

Cine clandestino durante el

tardofranquismo y la Transición

Ad Hoc

CENDEAC

Mateo muestra cómo la historia de la censura franquista es también la historia de la clandestinidad:

La clandestinidad no es [...] un afuera de lo visible, sino que su comportamiento y movimientos van a depender de la dia-

Cómo citar este artículo: MOLINA AGUDO, Inés, «MATEO LEIVAS, Lidia: El reverso de la censura. Cine clandestino durante el tardofranquismo y la Transición», Boletín de Arte-UMA, n..$^{42}$, Departamento de Historia del Arte, Universidad de Málaga, 2021, pp. 318-320, ISSN: 0211-8483, e-ISSN: 2695-415X, DOI: http://dx.doi.org/10.24310/ BoLArte.2021.vi42.12059 
léctica que se establece entre la censura y su reverso. [...] A pesar de la represión, a pesar del sufrimiento, del dolor y las pérdidas que conlleva, el control totalizante acaba generando, como efecto rebote, la creación de espacios radicales de la imaginación que se ubican más allá de todo lo posible (2020: 33).

Es decir, la clandestinidad cinematográfica emerge, precisamente, como consecuencia de los marcos impuestos por la censura. Por otra parte, esta no se experimenta como ocultamiento sino, más bien, como desafío a lo que el franquismo consideraba visible y decible. Para la autora, estas películas burlaban los «mecanismos de producción de verdad» movilizados por el régimen, incorporando temas borrados por los medios oficiales. Mateo nos remite a Jacques Rancière y su idea del «reparto de lo sensible», preguntándose quién ostentaba entonces el poder de ver y hablar. En el caso del cine, no solo debemos pensar en los mecanismos de control movilizados por la administración, a través de la Junta Superior de Censura Cinematográfica o el posterior Ministerio de Información, sino también en el monopolio informativo que ejercía el NO-DO desde 1938. El régimen limitaba la libertad de expresión mediante la censura previa, pero también la condicionaba de forma indirecta, promoviendo la creación de ciertas imágenes en detrimento de otras. De este modo, los colectivos de cine clandestino trataron de ampliar este «ordenamiento de lo sensible» desde sus películas, pero también desde sus modos de producción, distribución y exhibición.

Como desvela $O$ todos..., que contó con la participación y el apoyo de los trabajadores y sus familias, los propios modos de hacer resultaban enormemente significativos. Estos son analizados en la parte inicial del libro, «Prácticas cinematográficas clandestinas». A lo largo de los 70, emergen multitud de colectivos y cooperativas -Colectivo de Cine de Clase (1971), Colectivo de Cine de Madrid (1975), Grup de Producció (1975), El Volti (1971), entre tantos otros- que buscan responder al monopolio del NO-DO, TVE y las normas censoras. Recurriendo al asamblearismo y la democracia directa, los colectivos de cine no solo desafiaban la censura, sino también los propios dispositivos de la industria cinematográfica. En último término, rechazaban la «cultura burguesa», apuntalada por el encumbramiento del autor, así como la división social del trabajo, evitando la especializa- ción técnica e intelectual. De esta forma, la autora examina sus prácticas desde enunciados típicamente benjaminianos -los esbozados en «El autor como productor»-, considerándolas una toma de posición política, al tiempo que productoras últimas de sentido. Además, muestra cómo estas iniciativas respondían a un deseo de documentar y mostrar, tanto dentro como fuera de España, una realidad silenciada por el régimen.

¿Cuáles son, por tanto, las imágenes resultantes de estas prácticas? En la segunda parte del libro, «Imágenestestimonio: pueblo, violencia y memoria», la autora propone una posible ruta de acercamiento. Localiza para ello tres categorías o repertorios recurrentes en estas películas: por un lado, las imágenes que documentan la violencia estatal contra las huelgas y las disidencias en el último franquismo («violencia»); por otro, aquellas que transmiten saberes de lucha, organización y resistencia («pueblo»); y, por último, las que componen relatos históricos sobre el pasado reciente de España, especialmente en relación con la memoria de la Guerra Civil («memoria»). En este punto, Mateo hace énfasis en la experiencia del Colectivo SPA y su documental sobre la guerra, Entre la esperanza y el fraude (1975), realizado en un momento en el que existía un gran desconocimiento histórico "por fuera" de los relatos franquistas. Por otra parte, la represión franquista fue ampliamente documentada a través de rodajes a pie de calle, integrados después en documentales o noticiarios que confrontaban explícitamente a los medios informativos oficiales. A este respecto, la autora articula una reflexión sobre la memoria y el ejercicio historiográfico, deteniéndose en la manera en que estas películas logran recopilar un archivo fílmico-visual de este convulso pasado reciente.

Por último, en "Vida y muerte del cine clandestino", la historiadora despliega el mapa de las posibles trayectorias de estas imágenes clandestinas. Cabe detenerse en el modo en que Mateo recoge el testimonio de una espectadora, Marisa Fernández de Oleaga, quien acudió a la proyección clandestina de Vitoria (Colectivo de Cine de Madrid, 1976) en una parroquia de Gijón el año de su estreno. Movilizando un cuidadoso acercamiento desde la historia oral, Mateo traza las coordenadas para un «estudio ecológico de la percepción», que desborda el propio instante del visionado para proyectarse en un tiempo dilatado, pasado, presente y futuro, atendiendo a la memoria afectiva, corporal e histórica de la entrevistada. En esta última parte, el libro traza 
las últimas etapas del cine clandestino, que inevitablemente se agota con la abolición de la censura en 1977 (RD 11 de noviembre). Una vez que esta desaparece, se extinguen también los motivos para prolongar dichas prácticas.

El libro de Mateo, fruto de una tesis doctoral defendida en 2017, responde, en un primer momento, a una ausencia bibliográfica. Cabe mencionar, en este sentido, los trabajos pioneros de investigadores como Lydia García-Merás (2007) o Alberto Berzosa $(2014,2016)$, quienes se han preocupado por indagar en este "cine otro», marginal, alternativo o militante. Al mismo tiempo, esgrime una propuesta metodológica enormemente sugerente, recurriendo a enfoques relativos a los Estudios Culturales, los Estudios de la Memoria o la Affect Theory. Una metodología diseccionada por la autora en otro artículo (2020) que puede acompañar y enriquecer la lectura del libro, en tanto que explicita el propio proceso de trabajo. Decía Didi-Huberman que para comprender las «imágenes-luciérnaga», frágiles y efímeras, sedimentadas en el horizonte de la historia, estas debían ser miradas «en el presente de su supervivencia» (2012: 39). Es decir, se debía comprender la propia trayectoria de la imagen en el presen- te, su latencia actual. En este sentido, la reflexión metodológica esgrimida por Mateo tensa sus coordenadas hacia el momento inmediato: considera las sensaciones, indagaciones y reflexiones que acompañaron la búsqueda y visionado de estas películas, pero también las reapropiaciones que se han hecho de ellas en el presente, devolviéndoles su vitalidad. En el epílogo dedicado a las «supervivencias» de estas imágenes-testimonio, vuelve su mirada a las décadas recientes: filmes como No haber olvidado nada (Marcelo Expósito, Arturo Fito Rodríguez y Gabriel Villota, 1996) o Lo que no puede ser visto debe ser mostrado (María Ruido, 2010) rescatan fragmentos de estas películas, en las que se documentan protestas, huelgas y actos represivos en la década de los 70. Recogen, de algún modo, estas «imágenes en botellas lanzadas al mar» (2020: 181), otorgándoles un nuevo destino, contexto e intención. En definitiva, un lugar en el que reactivar saberes, memorias políticas, para un presente todavía encendido.
Inés Molina Agudo

Universidad Autónoma de Madrid

\section{Bibliografía}

BERZOSA, Alberto (2014), Homoherejías filmicas: cine homosexual subversivo en España en los setenta y ochenta, Brumaria, Madrid.

BERZOSA, Alberto (2016), «Aproximación a un cine proletario español durante el tardofranquismo y la transición», Historia, trabajo y sociedad, n. ${ }^{\circ} 7$, pp. 11-34.

BRECHT, Bertolt (1999), Bertolt Brecht: poemas y canciones, Alianza Editorial, Madrid.

DIDI-HUBERMAN, George (2012), Supervivencia de las luciérnagas, Abada Editores, Madrid.

GARCÍA-MERÁS, Lydia (2007), «El cine de la disidencia. La producción militante antifranquista (1967-1981)», en DESACUERDOS 4. Sobre Arte, Políticas Y Esfera Pública En El Estado Español, Arteleku-Diputación Foral de Gipuzkoa, Centro José Guerrero-Diputación de Granada, Museu d'Art Contemporani de Barcelona y Universidad Internacional de Andalucía-UNIA arte y pensamiento, Barcelona, Granada, San Sebastián, Sevilla, pp. 16-41.

MATEO LEIVAS, Lidia (2020), «How does a clandestine image behave? Proposal for a theoretical tool based on a Spanish civil war gaze», Visual Studies, DOI: 10.1080/1472586X.2020.1832909. 